\title{
Making waste minimisation a high impact activity in Southland, New Zealand
}

\author{
C. Dean \\ Invercargill City Council, FutureGenz Ltd, Invercargill, New Zealand
}

\begin{abstract}
Waste education in the Deep South of New Zealand is anything but boring!

For the past four years, schools and the general public have been enchanted, outraged, challenged and overjoyed by a steady stream of characters, storylines, clubs, events and challenges that have sprung forth from Southland's local waste educators. This lively approach to education is often so entertaining and engaging that the unsuspecting public barely even knows they're being educated. This is the pain-free method of education that we find works best.

Our educational messages are delivered through a wide variety of mediums and we regularly enlist the help of some 'larger than life' characters. These characters capture the imagination of our audiences and provide a 'face' that people can relate to easily.

The cornerstones of this successful approach to waste education are collaboration between agencies, offering a wide variety of opportunities for education, and providing comprehensive support for further exploration of the waste topic.

This paper describes the various aspects of our approach and discusses how we continue to make waste minimisation a high impact activity in Southland, New Zealand.

Keywords: waste minimisation, education, promotion, mediums, entertaining, collaboration, schools, community, Southland, New Zealand.
\end{abstract}

\section{Introduction}

Waste education in Southland is something of a success story, despite being afforded a relatively small budget in relation to many other regions' education programmes. 
The key players in waste minimisation are the local councils, who provide waste services and support this with education delivered by a dedicated Waste Minimisation Officer, or an Environmental Education Officer. Over time, the councils have developed a wide range of opportunities for education, and each year fresh new approaches are added. These include class visits, stage shows, weekly newspaper columns, DVD movies and long-term programmes that develop a deeper understanding of the issues.

The use of 'characters' is another unique element within these educational experiences that helps bring the material to life and create a memorable experience for the target audience. Creating characters is similar to the strategy of 'branding' in marketing. Likeable characters provide an 'image' that the public can easily identify with and feel a positive association for in the future.

Staff from the individual councils also collaborate regularly on education and network with other likeminded agencies, such as the Department of Conservation, Southland Museum and Art Gallery, Southern Institute of Technology and relevant community groups. Working in this way creates powerful synergies and achieves far greater outcomes than if everyone worked in isolation.

\section{Background}

Located in the southernmost region of New Zealand, Southland is largely a farming province with a population of approximately 90,000 people (about 50,000 of these live in the main city of Invercargill). The Southland community is generally considered to be conservative and fairly resistant to change, including changes to the 'tried and true' methods of disposing of waste.

Nationally, the concept of waste minimisation was fairly slow to gather momentum, largely due to New Zealand's small population (4 million) and the fact that land for waste disposal has been historically easy to access. However, over the last decade there have been some changes. Landfills are now required to meet far more stringent environmental standards and the associated costs of landfilling have risen steadily, along with stronger public sentiment in support of waste minimisation. Consequently, waste minimisation and education have become a higher priority.

In terms of legislation, councils have an obligation to provide for efficient and effective waste management, and to consider disposal options based on the $5 \mathrm{R}$ waste hierarchy - Reduce, Reuse, Recycle, Recover, Residual. However, waste minimisation is not compulsory and there are no mandatory waste reduction targets - only suggested targets in the National Waste Strategy. This set of circumstances has made waste minimisation a nice ideal, but certainly not imperative. 


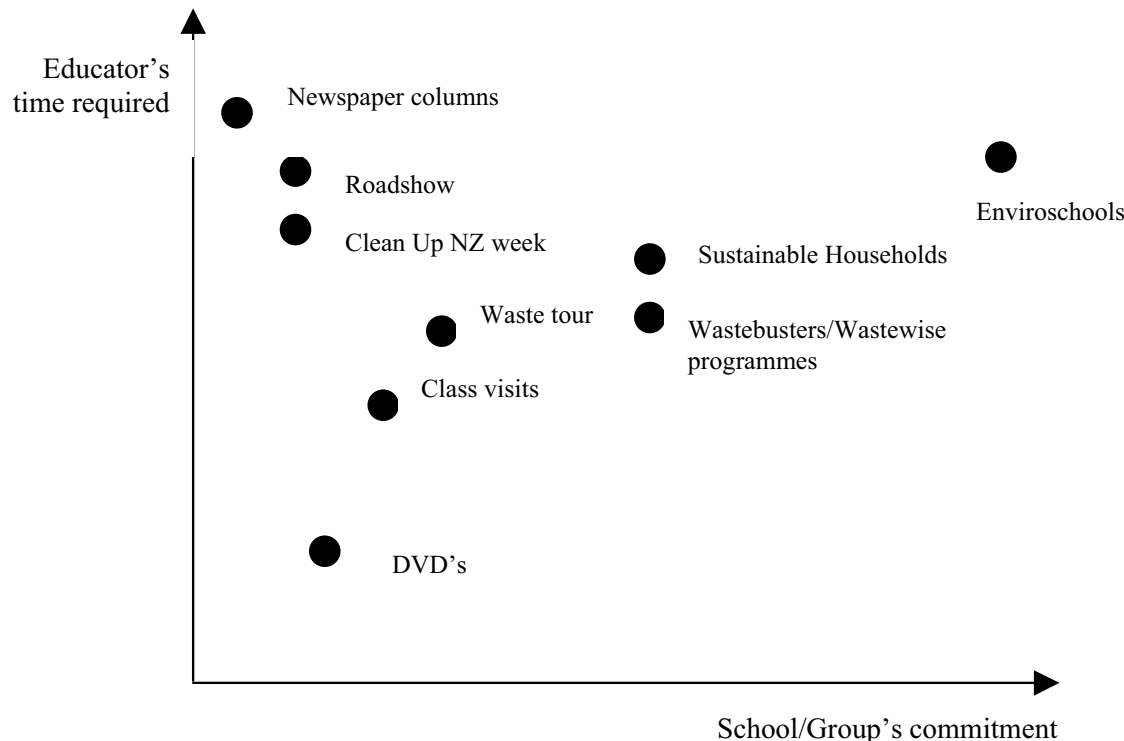

Figure 1: Relative time commitment required for various education opportunities.

\section{Discussion}

\subsection{Overview of approaches}

Over a period of time, educators in Southland have built up an interesting repertoire of tools that enable schools and communities to explore the topic of waste to varying degrees. Many of these tools are listed below:

- Enviroschools programme

- Brucie/Lucy visits

- Educator visits

- Clean Up NZ week

- Reduce your Rubbish Roadshow

- Corporate Clean up Challenge

- Museum programmes/ screenings

- Wastebusters programme

- Wastewise worm farming

- Beat the Rubbish Blues DVD

- Trashtalk DVD

- Brucie's Buddies club

- Sustainable Households programme 
- Lucy Grubb newspaper column

- Southland Wastebusters column

- Waste tour of facilities

Given that time is a significant restraint for educators and their audiences alike, this variety of programmes offers something that will suit most schedules. Figure 1 shows some of the relative time commitments.

\subsection{Clean Up New Zealand week}

Clean Up NZ week is a nationally co-ordinated campaign that encourages local areas to undertake their own 'clean up' activities for a week in September each year. Locally, Southland council's and other environmental agencies get together to plan a campaign that will inspire and motivate the community and provide an opportunity to take action. Planning for this week usually begins around May and staff time is fairly solidly committed to Clean Up Week activities throughout the month of September, followed by debriefing in October. Events include:

- Advertising campaigns

- Registering groups to undertake litter 'clean ups' in their community

- Providing free bags and gloves for those undertaking clean ups

- A Corporate Challenge for local businesses to 'clean up' an area

- A 'Roadshow' around Southland schools with colourful characters

\subsection{Reduce Your Rubbish Roadshow}

The Roadshow is generally held during Clean Up NZ week. Staging this event requires educators to develop a 25 minute 'show', source props and costumes, co-ordinate travelling to schools, handle equipment such as cameras, laptop and projector and play the characters in the show.

With three staff from the local councils, plus an additional helper, the travelling Roadshow visits twenty schools in one week, reaching approximately 2000 pupils with the 3 R's (Reduce, Reuse, Recycle) and 'clean up' messages. The main costs are staff time, travel expenses and some props and costumes, which are often picked up second-hand.

\subsection{Characters}

- Bruce C Gull (www.brucecgull.com)

Brucie (as he is known to his friends) is a character developed to assist with education about various environmental messages, including recycling and waste issues. With his mischievous antics and big hugs he is loved by children and enjoyed by adults everywhere he goes. 
Brucie visits schools, attends many events and has his own club for children, which enables 'Brucies Buddies' to feel like they are helping Brucie to look after the environment. This concept has helped to mould a generation of youngsters who feel positive about environmental messages because of their early experience.

\section{- Lucy Grubb}

The Lucy Grubb character enables educators to demonstrate the wrong way to deal with rubbish. She is a naive old granny who thinks that these 'new-fangled' ideas about recycling are 'a load of old cods wallop' and advocates throwing rubbish out the window. Children know (helped along by Brucie) that Lucy is doing the wrong things, but they agree to help her learn the right ways when she asks for their help. This process helps to cement the children's own knowledge, or teach positive behaviours to those who are new to the concepts.

\section{- Peti}

Peti is the starring character in the recently produced 'Beat the Rubbish Blues' DVD that explores waste issues in a local context. Peti, a carefree student who learns about the $3 \mathrm{R}$ 's, is a character with wide appeal, particularly for students and Maori/Polynesian audiences.

\section{- Can and Apple}

Can and Apple are animated characters in another DVD movie called Trashtalk. In this ten minute movie, Can and Apple are on a quest to become something more than just litter - they want to reach the ultimate goal of being recycled. Their story appeals to children of all age groups and is suitable for pre-school children as an introduction to recycling.

\subsection{Newspaper columns}

The Invercargill City Council runs a weekly column in the free newspaper called 'The Southland Express', which is a popular publication with wide readership. The column is written from the perspective of Lucy Grubb, who is described in Section 3.4.

The local community group, Southland Community Wastebusters Trust, also have a weekly column in the region's principal paper, The Southland Times, which the Times print free of charge. Council staff collaborate with volunteers from the Trust to plan and write these columns, which is an ideal forum to promote topical issues. 


\subsection{DVDs}

DVD's are always popular with children and this is an ideal medium for schools. The local councils have recently collaborated on two DVD's that provide an interesting overview of waste in the region, where it goes and the more sustainable alternatives of Reduce, Reuse and Recycle.

\subsection{Ongoing education programmes}

The council's educators provide programmes to schools and community groups. These can vary from a single visit to a comprehensive programme that requires a more significant commitment and therefore provides for a deeper understanding of the issues.

\section{- Waste talks}

Educators visit a classroom to give an overview of waste issues. Resources used can include DVD's, examples of recyclable material and samples of products made from recycled and biodegradable materials.

\section{- Wastewise worm farming}

A school commits to a series of three visits by an educator to learn about organic waste and worm farming as a way of recycling. The school then sets up a worm farm with the educator and they are periodically revisited by the educator to check progress.

\section{- Wastebusters programme}

Schools can choose to take part in one of four modules delivered by an educator - worm farming, composting, paper recycling or zero waste. The modules include videos, songs and practical or theoretical activities to support learning.

\section{- Enviroschools (www.enviroschools.org.nz)}

The Regional Council (Environment Southland) is the local provider for this nationally co-ordinated programme. Interested schools are required to make a three year commitment to the programme, which enables them to become an 'Enviroschool'. Enviroschools are supported in their journey by a trained facilitator and a comprehensive education kit which guides teachers through five topic areas. The programme also provides for professional development opportunities for teachers, attendance to the national 'hui' (get-together), a regional event each year and the option of entering into an awards scheme for achieving Enviroschool milestones. 
- Sustainable Households (www.sustainablehouseholds.org.nz)

This programme is also nationally based and regionally co-ordinated. It is targeted at the wider community i.e. households, and enables individuals to learn about ways they can be more sustainable at home. A facilitator delivers several sessions covering topics such as waste, water, transport, shopping, organic gardening and so on. Sessions are generally held in the evening with people who have registered for the programme. A website supports these sessions and participants are able to access a wide range of additional information.

\subsection{Collaboration}

The common factor and essential ingredient for education in Southland has been collaboration. By working together we are able to stage major events and fund more programmes than we could as individual entities. We can also access a wider range of skills and experience when needed, which results in more successful outcomes.

Within the area of waste education, the key players are the local councils who employ either a Waste Minimisation Officer or an Environmental Education Officer. Other agencies that also have some common objectives are the Department of Conservation, the Southern Institute of Technology, the Southland Museum, the Southland Wastebusters Trust, the Invercargill Environment Centre, Venture Southland and other councils in neighbouring provinces. Southland's councils have liased and worked with all of these agencies to achieve common goals and to maximise efficiencies.

By collaborating in this way, the 'reduce your waste' message remains consistent and becomes somewhat omnipotent. This is a very powerful way to exert pressure on people to change their behaviour, and is ultimately more effective than councils just 'wagging their finger'.

\section{Results}

Generally speaking, more effort tends to go into developing and delivering educational opportunities than into evaluating the results in a quantitative way, which is an area where improvements could be made. However, some results are as follows:

- The 'Roadshow' visits 20 schools over one week each year, and directly reaches about 2,000 students, plus teachers and parents. It also engages the media and has regularly featured in the two local newspapers, local television and radio.

- Evaluation of the Roadshow in 2004 showed that students' knowledge of all the show's key environmental messages had improved after watching the show, and that learning had been retained for at least three weeks after the show (when post-surveying took place). Anecdotal evidence 
suggests that children still remembered and talked about the show many months later.

- Following a visit from the Roadshow, a number of schools went on to study waste as a major term topic (1/4 of the school year) in the following year.

- 55 guests (maximum capacity) attended the launch of the 'Beat The Rubbish Blues' DVD, including teachers, principals, councillors and community group representatives. Every school in Southland has been given a copy of the DVD.

- Participation in kerbside recycling in Invercargill has steadily increased since its introduction in 2003, and is now estimated to be around 70$80 \%$.

- Brucie's Buddies club has membership of approximately 2,700 children and each year 350 children and parents attend his birthday party.

\section{Conclusions}

We consider our achievements to be considerable on what are relatively limited resources. Through collaboration, Southland educators and agencies are successful in keeping waste in the public eye at all times, through a variety of mediums, and public sentiment towards waste minimisation is positive. Some key conclusions from our experiences include:

- A variety of approaches keeps educational material fresh and reaches the widest possible range of people, from pre-schoolers to adult community groups, to individuals who need only pick up the newspaper to learn about waste minimisation.

- Creating a likeable character is similar to the marketing technique of 'branding' which helps to create positive associations for your message and provides a non-confrontational way to teach people.

- Collaboration with a wide range of groups maximises efficiencies, reduces costs, increases the skill base and maximises coverage of the message.

- A consistent message that comes from a range of sources, including community groups, is more likely to generate the social peer pressure that causes behaviour change. 